\title{
Thematic Progression Pattern : A Technique To Improve Students' Writing Skill Viewed From Writing Apprehension
}

\author{
Fitri Nurdianingsih \\ IKIP PGRI Bojonegoro \\ fitriafip12@gmail.com \\ Yuniarta Ita Purnama \\ IKIP PGRI Bojonegoro \\ niarpurnama@gmail.com
}

\begin{abstract}
The objective of conducting this research was to find out : (1) whether or not the use of thematic progression pattern is more effective than direct instruction in teaching writing to the second semester students at English Education Department; (2) the students who have a low writing apprehension have better writing skill than those who have a high writing apprehension; and (3) there is an interaction between teaching technique and writing apprehension in teaching writing skill. This research was an experimental research design. The population of this research was the second semester students at English Education Department of IKIP PGRI Bojonegoro. Meanwhile the sample of this research was selected by using cluster random sampling. The instruments of data collection were writing test and writing apprehension questionnaire. The findings of this study are: (1) thematic progression pattern is more effective than direct instruction in teaching writing; (2) the students who have low writing apprehension have better writing skill than those who have high writing apprehension; and (3) there is an interaction between teaching technique and writing apprehension in teaching writing skill. It can be summarized that thematic progression pattern is an effective technique in teaching writing skill at the second semester students of English Education Department in IKIP PGRI Bojonegoro. The effectiveness of the technique is affected by writing apprehension.
\end{abstract}

Keywords: thematic progression pattern, writing skill, and writing apprehension 


\section{INTRODUCTION}

Among the language skills, writing seems to be the most difficult one in the sense that it needs a long process starting from brainstorming up to final product. Furthermore, it involves some writing elements such as content, grammatical function, vocabulary, and the mechanics like punctuation, capitalization, and spelling.

Writing belongs to the productive skill that should be mastered by the students in order to communicate their ideas and feeling with others in written form. In line with this statement, Raimes (1983) states that writing is a skill in which we express the ideas, feelings, and thoughts arranged in words, sentences and paragraphs using eyes, brain, and hand. According to ( Tarigan, 1987 ; Arbain, 2017), writing is a language skill that is used for indirect communication. the students can communicate their ideas and thoughts to others through written form such as letter, message, or invitation for communication.

Writing is a complex process of an activity that allows one in transforming thoughts, constructing ideas, discovering meaning and organizing them into sentences and paragraphs which focuses on content first using the appropriate language through several stages rehearsing, drafting, and revising. There are five aspects of writing according to Brown \& Bailey (1984), namely: organization, content, grammar, mechanics, and style.

Writing skills assisted the students to express their ideas in the written form. Thus, they have to master English vocabulary and tenses as the main part in constructing ideas. In fact, the students got some difficulties in writing skill, such as the lack of vocabulary and tenses. To solve this problem, the researcher conduct the research to find what method that is effective in teaching writing skill.

Writing required not only cognitive aspect but also affective aspect that could influence students. McLeod cited in Alnufaie \& Grenfell (2013) writing is claimed to be an emotional as much a cognitive activity. Its affective constituents including emotions, apprehension and motivation influence all stages of the writing process.

This research is aimed to identifying the effect of the teaching techniques and writing apprehension on students' writing skill. Particularly this research is proposed whether or not : (1) the use of thematic progression pattern is more effective than direct instruction in teaching writing to the second semester students at English Education Department; (2) the students who have a low writing apprehension have better writing skill than those who have a high writing apprehension; and (3) there is an interaction between teaching technique and writing apprehension in teaching writing skill. 
Nunan (2009) mentions that writing is an activity that can usefully be prepared for by work in the other skills of listening, speaking and reading. It also significant to make sure that writing can reflect the students' perform in their daily lives. In writing, the students are required to produce language to express their ideas. To do this, they should have sufficient knowledge of what to write and organization of language. Knowing what to write will enable the flow of ideas, whereas knowing how to organize will help them convey the ideas in a clear way to the readers. To produce good writing, it is necessary for the students to know how to organize Theme and Rheme in their writing.

The organization of Theme and Rheme is usually discussed in Systemic Functional Grammar. It is a multi-functional view of language in which each meta fiction assigns a structure to the clause. Systemic Functional Grammar view language as a resource for making meaning. This grammar attempts to describe language in actual use and so focuses on text and their context. There are three types of meaning within grammatical structures in grammar as resource for making meaning, they are experiential/ideational meaning, interpersonal meaning, and textual meaning. Textual meaning is relevance to the context: both the preceding (and following) text, and the context of situation. The textual function of the clause are that of constructing a message. It is constructed in English in term of Theme and Rheme. The system of Theme belongs to the textual meta function of the language. It is concerned with the organization the larger text. Every clause is organized as a message related to an unfolding text.

Halliday (1994) states that Theme is the element which serves as the point of departure of the message; it is that with which the clause is concerned. The remainder of the message, the part in which Theme is developed is called Rheme. As a message structure; therefore, a clause consists of a Theme accompanied by a Rheme; and the structure is expressed by the order whatever is chosen as Theme is put first.

The Rheme is the most important element in the structure of the clause as a message because it represents information the speaker wants to convey to the hearer. It is the Rheme that fulfils the communicative purpose of the utterance. Gerot \& Wignell (1994) mention that in English the Theme can be identified as that or those element (s) which come(s) first in the clause. This represents the point of departure of this message from the previous one. The rest of the clause is called Rheme. New information is typically contained in the Rheme. 
Paltridge (2000) says that the notion of Theme and Rheme are also employed in the examination of thematic progression, or method of development of a text. Thematic progression refers to the way in which the Theme of a clause may pick up, or repeat, a meaning from a preceding Theme or Rheme. There are three kinds of thematic progression patterns, they are: reiteration or constant theme pattern, zig-zag/ linear theme pattern, and multiple theme/ split rheme pattern.

In writing, the students should pay attention not only to grammar, punctuation and capitalization, unity and coherence, but also to its thematic progression. It means how they develop old and new information in their writing. Based on the statements above the writer is interested in conducting this research with several considerations. First, the writer wants to know what are themes and rhemes in the students' writing, and second she is also eager to know what thematic progression pattern they employ in developing their writing.

Butt (2000) say that if the Theme is the signpost for a speaker or writer's point of departure, then each Rheme is the temporary destination. Usually the bit of the message that the writer or speaker considers interesting or important comes in the Rheme. While the first clause or clause complex in a text will probably contain all new meanings, the thematic choices for the following clauses should not be unexpected. They should be connected with ideas that we have already met in the Theme or Rheme of a clause or not too far before.

Because readers and addressees need to be reassured that they are following the development of the text, many texts are signposted by placing elements from the Rheme of one clause into the Theme of the text, or by repeating meanings from the Theme of one clause in the Theme of subsequent clauses. This kind of text development method is called thematic progression.

Arends (1997) mentions that direct instruction is a conventional teaching that assists the students to learn basic skill and acquire information that can teach in step by step. Direct instruction mainly focuses on teacher-centered, emphasizes the use of small group, face-toface instruction by the teacher and provides learners with practically useful knowledge of language.

Daly \& Miller (1975) coined the term writing apprehension is meaning writing-specific anxiety. According to Magno (2008), writing apprehension can be conceptualized as a significant predictor to determine the success rate of acquiring English Language proficiency among ESL learners. Hettich (1994) defines that writing apprehension as the abnormally high level of an anxious, nervous, agitated or stressful feeling in a writing strategy related 
situation, regardless of blocking and evaluation. As psychological aspect, writing apprehension has the significant role which affects students in learning writing. It appears when students do not have positive feeling and belief about writing. They tend to have negative attitudes when their writing is being evaluated. These kinds of negative feeling, belief and attitudes should be avoided by students.

The hypotheses of this research can be formulated as follows: (1) thematic progression pattern is more effective than direct instruction in teaching writing to the second semester students at English Education Department; (2) the students who have a low writing apprehension have better writing skill than those who have a high writing apprehension; and (3) there is an interaction between teaching technique and writing apprehension in teaching writing skill.

\section{METHODOLOGY}

The design of this study is an experimental research. It was carried out at second semester students of English Education Department in IKIP PGRI Bojonegoro. This study was conducted from April up to July 2017. This research had two classes, one class as the experimental class and one as the control class. The researcher used two instruments of collecting data, namely writing test and writing apprehension questionnaire. Writing test was used to measure the students' writing ability by using scoring rubrics of writing. Meanwhile writing apprehension questionnaire was used to measure the level of students' writing apprehension. The technique used in analyzing the data were descriptive and inferential analysis. Descriptive analysis was to know the mean, median, mode, and standard deviation of the scores of the writing test. Then, the researcher identify the normality and the homogeneity of the data (Nur, 2016) \& (Arbain, 2016). Inferential analysis used Multifactor analysis of variants $2 \times 2$ to test the hypotheses. The analysis was continued to identify which group is better by using Tukey test.

\section{FINDINGS}

Before testing the hypotheses, the researcher computed the normality and the homogeneity of the data. The result of normality test for the groups: (1) the writing scores computation of the students who taught using thematic progression pattern $\left(\mathrm{A}_{1}\right)$ shows that $\mathrm{L}_{\mathrm{o}}$ (0.1517) is lower than $\mathrm{L}_{\mathrm{t}}(0.1618)$, it can be concluded that the first group is in normal distribution; (2) the writing scores computation of the students who taught using direct instruction $\left(\mathrm{A}_{2}\right)$ it shows that $\mathrm{L}_{\mathrm{o}}(0.1546)$ is lower than $\mathrm{L}_{\mathrm{t}}(0.1618)$, it can be concluded that 
the second group is in normal distribution; (3) the writing scores of the students who have high apprehension $\left(\mathrm{B}_{1}\right)$ shows that $\mathrm{L}_{\mathrm{o}}(0.1357)$ is lower than $\mathrm{L}_{\mathrm{t}}(0.1618)$, it can be concluded that the third group is in normal distribution; (4) the writing scores of the students who have low apprehension $\left(B_{2}\right)$ shows that $L_{o}(0.1519)$ is lower than $L_{t}(0.1618)$, it can be concluded that the fourth group is in normal distribution; (5) the writing scores of the students who have high apprehension which is taught by using thematic progression pattern $\left(\mathrm{A}_{1} \mathrm{~B}_{1}\right)$ shows that $\mathrm{L}_{\mathrm{o}}(0.1197)$ is lower than $\mathrm{L}_{\mathrm{t}}(0.2200)$, it can be concluded that the fifth group is in normal distribution; (6) the writing scores of the students who have low apprehension which is taught by using direct instruction $\left(\mathrm{A}_{2} \mathrm{~B}_{1}\right)$ shows that $\mathrm{L}_{\mathrm{o}}(0.1976)$ is lower than $\mathrm{L}_{\mathrm{t}}(0.2200)$, it can be concluded that the sixth group is in normal distribution; (7) the writing scores of the students who have low apprehension which is taught by using thematic progression pattern $\left(\mathrm{A}_{1}\right.$ $B_{2}$ )shows that $L_{o}(0.1707)$ is lower than $L_{t}(0.2200)$, it can be concluded that the seventh group is in normal distribution; and (8) the writing scores of the students who have low apprehension which is taught by using direct instruction $\left(\mathrm{A}_{2} \mathrm{~B}_{2}\right)$ shows that $\mathrm{L}_{\mathrm{o}}(0.2106)$ is lower than $\mathrm{L}_{\mathrm{t}}(0.2200)$, it can be concluded that the eighth group is in normal distribution. In sum up, all the data of writing scores for the eight groups are in normal distribution because $L_{o}$ of the entire data are lower than $L_{t}$ at the level of significance $\alpha=0.05$.

The result of homogeneity test is 3. 83. Because $\chi_{0}^{2}(3.83)$ is lower than $\chi_{t}^{2}(7.81)$, it can be concluded that the data are homogeneous. From the calculation of normality and homogeneity analysis, the data of this research are normal and homogeneous. Then, the data are analyzed by using Multifactor Analysis of Variance 2x2 to identify the effects of writing apprehension and the techniques in teaching writing skill.

\begin{tabular}{|lllllll|}
\hline \multicolumn{1}{|c}{ Source of variance } & SS & df & MS & Fo & Ft(.05) \\
\hline Between columns (technique) & 248,0667 & 1 & 248,0667 & 269,2196 & 4,03 \\
\hline Between rows(apprehension) & 147,2667 & 1 & 147,2667 & 159,8243 & 4,03 \\
\hline Columns by rows (interaction) & 6,666667 & 1 & 6,666667 & 7,235142 & 4,03 \\
\hline Between groups & 402 & 3 & 134 & & \\
\hline Within groups & 51,6 & $\mathbf{5 6}$ & $\mathbf{0 , 9 2 1 4 2 9}$ & & \\
\hline \multicolumn{1}{|c|}{ Total } & 453,6 & 59 & & & \\
\hline
\end{tabular}

\section{Table 1 the summary of a $2 \times 2$ Multifactor Analysis of Variance}

Based on the summary of 2 x 2 Multifactor Analysis of Variance (ANOVA) above, some interpretations can be drawn as follows: 
1. The impacts of teaching techniques upon the students' writing ability. Based on the table 1, it can be seen that Thematic Progression Pattern is more effective than Direct Instruction to teach writing.

2. The effect of writing apprehension upon the wtudents' writing ability. Based on the table 1, it can be seen that the students who have low apprehension have better writing skill than the students who have high apprehension.

3. The interaction effect of teaching techniques and writing apprehension. Based on the table, it can be seen that there is an interaction effect between teaching techniques and creativity upon students' writing skill. Thus, the efect of teaching techniques on performance of writing depende on the writing apprehension.

In order to compare the mean of every treatment with the other means using Tukey test. This test is used to identify which means are significantly different from the other.

\begin{tabular}{|ccccl|}
\hline Between groups & qo & qt(.05) & Meaning & Category \\
\hline $\mathrm{A}_{1}-\mathrm{A}_{2}$ & 23.2005 & 2.89 & qo $>$ qt & Significant \\
\hline $\mathrm{B}_{1}-\mathrm{B}_{2}$ & 17.8825 & 2.89 & qo $>$ qt & Significant \\
\hline $\mathrm{A}_{1} \mathrm{~B}_{1}-\mathrm{A}_{2} \mathrm{~B}_{1}$ & 19.0964 & 3.01 & qo $>$ qt & Significant \\
\hline $\mathrm{A}_{1} \mathrm{~B}_{2}-\mathrm{A}_{2} \mathrm{~B}_{2}$ & 13.7181 & 3.01 & qo $>$ qt & Significant \\
\hline
\end{tabular}

Table 2 The Summary of Tukey Test

Based on the summary of Tukey test above, the interpretations can be drawn as follows:

1. Comparing two means between-columns. By comparing two means betweencolumns $\left(\mathrm{A}_{1}-\mathrm{A}_{2}\right)$, it can be found that the value of $\mathrm{q}_{\mathrm{o}}(23.20)$ is higher than $\mathrm{q}_{\mathrm{t}}$ (2.89), so the two techniques differ significantly. Therefore, it can be concluded that thematic progression pattern is more effective than direct instruction in teaching writing skill.

2. Comparing two means between-rows. By comparing two means between-rows $\left(\mathrm{B}_{1}-\mathrm{B}_{2}\right)$, it can be found that the value of $\mathrm{q}_{\mathrm{o}}(17.88)$ is higher than $\mathrm{q}_{\mathrm{t}}(2.89)$, so the two level of writing apprehension differ significantly. Therefore, it can be concluded thatthe students who have low writing apprehension have better writing skill than the students who have high writing apprehension.

3. Comparing two means columns by rows. By comparing two means columns by rows $\left(A_{1} B_{1}-A_{2} B_{1}\right)$, it can be found that the value of $q_{o}$ (19.09) is higher than $\mathrm{q}_{\mathrm{t}}$ (3.01), so the students who have high apprehension and taught by using thematic progression pattern are significantly different from the students who 
have high apprehension and taught using direct instruction. Therefore, it can be concluded that the students who have high apprehension and taught by using thematic progression pattern have better writing skill than the students who have high apprehension and taught by using direct instruction.

4. Comparing two means columns by rows. By comparing two means columns by rows $\left(A_{1} B_{2}-A_{2} B_{2}\right)$, it can be found that the value of $q_{o}$ (13.71) is higher than $\mathrm{q}_{\mathrm{t}}(3.01)$, so the students who have low apprehension and taught by using thematic progression pattern are significantly different from the students who have low apprehension and taught by using direct isntruction. Therefore, it can be concluded that the students who have low apprehension and taught by using thematic progression pattern have better writing skill than the students who have low apprehension and taught by using direct instruction.

\section{DISCUSSION}

From the findings of this research, it can be seen that thematic progression pattern was effectively improve students writing skill in terms of organization. The findings were in line with some researches which deal with the usefulness of T/TP as a tool to characterize EFL/ESL writing as successful or less successful in terms of coherence (Bloor \& Bloor, 1992; Christie \& Dreyfus, 2007; Rørvik, 2012; Schleppegrell, 2004, 2009; Vande Kopple, 1991; Wang, 2007; Wei, 2013a, 2013b; Wei, 2014). However, as Hawes \& Thomas (2012) pointed out, while native speakers of English may have acquired how to use T/TP to produce coherent discourse when they grow up learning the language, EFL/ESL students are yet to learn what kind of information to place in the Theme position and how to continually pick up the information which is already in the text and repeat it in some way so that the reader is always aware of what the key concepts are and how the key concepts are being developed (Hyland, 2004).

TPP activity gives students the opportunity to apply the knowledge of T/TP they acquired in previous sessions and practice identifying T/TP patterns in short texts before they attempted to analyze longer texts. The identification of the thematic structure of the text is accompanied by a discussion on how the information flows to make the text coherent which could help students understand how the meaning and purpose of a text unfolded when these elements were effectively arranged (Christie \& Dreyfus, 2007).

Thematic progression pattern construct can be a valuable instrument for teachers because it allows students to focus on the level of text, and to thereby explain to students 
where they are losing effectiveness while reading due to problems with either TP or Thematic selection, or both. (Alonso \& McCabe, 2003) were pointed out that English learners often wrote essays that consisted of sentences which did not seem to connect into a cohesive text and more attention should be paid to the progression of information in texts in addition to focus on cohesive devices. Wang (2007) claimed that the theory of T/TP was a valuable tool for teachers to diagnose writing difficulties and students should be taught how to arrange old and new information to help improve cohesion and coherence in their writing.

Otherwise, (Cruickshank \& Metcalf, 1999) state that Direct Instruction seems to satisfy the students because they just become the follower and depend on help. Berlitz (2011) argues that direct instruction is a traditional method focused on teacher-centered. It is characterized by teacher-dominated classroom. Direct instruction refers to the classroom activities which are totally led by the teacher.

In the teaching and learning process, students who have high apprehension have difficulties in exploring ideas and they are passive to learn in the class. In writing activities, they do not list points of ideas and they just stuck or stop doing writing until they have ideas. On the other hand, students who have low apprehension write significantly more paragraphs, sentences, than the students who have high apprehension. They tend to be active in the teaching and learning process. Daud \& Abu Kasim (2015) mention that the students who have low apprehension tend to achieve higher grades in compocition courses than those the students who have high apprehension.

\section{CONCLUSION}

The conclusion of this study can be summarized as follows: (1) the students taught using thematic progression pattern have better writing skill than those taught using direct instruction for the second semester students at English Education Department of IKIP PGRI Bojonegoro; (2) the students having low writing apprehension have better writing skill than those having high writing apprehension for the second semester students at English Education Department of IKIP PGRI Bojonegoro; and (3) there is an interaction between teaching method and writing apprehension in teaching writing skill.

Therefore, it is recommended that: (1) thematic progression pattern could be used as teaching technique in order to improve the students' writing skill; (2) the students who have high writing apprehension should have positive thinking that even they have done the mistakes and errors, they do not need being worried to be evaluated by the teacher; and (3) 
there are probably some weaknesses in this study which should be considered by other researchers to conduct better research.

\section{BIBLIOGRAPHY}

Alnufaie, M., \& Grenfell, M. (2013). EFL writing apprehension: the macro or the micro? Journal of Arts and Humanities, 79-89.

Alonso, S., \& McCabe, A. (2003). Improving text flow in ESL learner compositions. The Internet TESL Journal, 9(2).

Arbain, A. (2016). Critical Discourse Analysis of Eminem 's " Love the Way You Lie Part II ." Script Journal, 1(1), 1-10. https://doi.org/10.24903/sj.v1i1.19.g8

Arbain, A. (2017). Students narrative essay construction ability. JELE (Journal of English Language and Education), 3(1), 63-68. https://doi.org/https://doi.org/10.26486/jele.v3i1.255

Berlitz, M. (2011). Direct Method.

Bloor, M., \& Bloor, T. (1992). Given and new information in the thematic organization of text: An application tothe teaching of academic writing. Occasional Papers in Systemic Linguistics, 33-43.

Brown, J. D., \& Bailey, K. M. (1984). A Categorical Instrumental for Scoring Second Language Writing Skills. Language Learning, 21-42.

Butt, D. et. al. (2000). Using functional grammar. An explorer's guide. Sydney: National centre for English language teaching and research.

Christie, F., \& Dreyfus, S. (2007). Letting the secret out: Successful writing in secondary English. Australian Journal of Language and Literacy, 11(3), 235-247.

Cruickshank, D. ., \& Metcalf, K. K. (1999). The Act of teaching. New York: Macgraw-Hill College.

Daly, J., \& Miller, M. D. (1975). Apprehension of Writing as a predictor of message intensity. The Journal of Psychology, 173-177.

Daud, N. M., \& Abu Kasim, N. L. (2015). Writing Anxiety: Causeor Effect. Malaysian Journal of ELT.

Gerot, L., \& Wignell, P. (1994). Making Sense of Functional Grammar. New South Wales: Gerd Stabler.

Halliday, M. A. K. (1994). An Introduction to Functional Grammar. Second Edition. London: Edward Arnold. 
Hawes, T., \& Thomas, S. (2012). Theme choice in EAP and media language. Journal of English for Academic Purposes, 11(3), 175-183. https://doi.org/10.1016/j.jeap.2012.04.005

Hettich, R. L. (1994). Writing apprehension: critique. Purdue University.

Hyland, K. (2004). Genre and Second Language Writing. English for Specific Purposes (Vol. 27). https://doi.org/10.1016/j.esp.2007.07.002

Nur, D. R. (2016). An Analysis of Derivational Affixes in Commencement Speech. Script Journal, 1(1), 25-35. https://doi.org/10.24903/sj.v1i1.18

Paltridge, B. (2000). Makingsense of discourse analysis. Australia: Gerd Stabler.

Raimes, A. (1983). Techniques in teaching writing. New York: Oxford University Press.

Rørvik, S. (2012). Thematic progression in learner language. In S. Hoffmann, P. Rayson, \& G. Leech (Eds.), English corpus linguistics: Looking back, moving forward (pp. 165177).

Schleppegrell, M. J. (2004). The language of schooling: A functional linguistics perspective. Mahwah: LawrenceErlbaum.

Schleppegrell, M. J. (2009). Grammar for generation 1.5.: A focus on meaning. (M. Roberage, M. Siegal, \& L.Harklau, Eds.), Teaching academic writing to U.S.educatedlearners of ESL. New York: Routledge.

Vande Kopple, W. J. (1991). Themes, Thematic Progressions, and Some Implications for Understanding Discourse. Written Communication, 8(3), 311-347. https://doi.org/10.1177/0741088391008003002

Wang, L. (2007). Theme and rheme in the thematic organization of text: Implications for teaching academicwriting. Asian EFL Journal, 164-176.

Wei, J. (2013a). Corpus-based research on the development of thematic choices in Chinese learners' Englishspeech. Journal of Education and Practice, 38-45.

Wei, J. (2013b). Corpus-based research on topical thematic choices in Chinese and Swedish English learners'English writing. Theory and Practice in Language Studies, 2202-2208.

Wei, J. (2014). Theme and thematic progression in learner English: A literature review. Colombian AppliedLinguistics Journal, 67-80. 